\title{
Age and growth rates of North Atlantic eel larvae (Anguilla spp.), based on published length data
}

\author{
F.-W. Tesch \\ Biologische Anstalt Helgoland; Notkestr. 31, \\ D-22607 Hamburg, Germany
}

\begin{abstract}
The age of glass eels arriving at the European coasts is estimated by different authors to range from $3 / 4$ to $3+$ years; some of these estimates are based on counts of "daily rings". The present study reviews published data on North Atlantic length frequency distributions. The only years for which larvae samples are available from the spawning area to the European continental slope are 1979 and, to a certain extent, also 1922. In the spring of both years, length frequency distributions exhibited two distinct maxima which are considered to belong to the AG 0 (mean lengths 12 and $18 \mathrm{~mm}$ for 1979 and 1922, respectively) and the AG I ( 47 and $44 \mathrm{~mm}$ ). In addition, a third, less distinct maximum is visible and the existence of an AG II must be considered. Growth during the first year of life is calculated using the means of total lengths of sufficiently large samples, collected with progressing season, of the years $1920,21,22,79,81$. From the resulting linear regressions for Anguilla anguilla until the beginning of winter, a daily length increase of $0.15 \mathrm{~mm}$ was estimated. Growth of A. rostrata was faster $\left(0.22 \mathrm{~mm} \cdot\right.$ day $\left.^{-1}\right)$. Daily length increase of $A$. anguilla in winter was only $0.03 \mathrm{~mm}$; during a possible second summer $0.06-0.09 \mathrm{~mm} \cdot \mathrm{day}^{-1}$ and during a possible third summer considerably less. There is a length increase of the European eel larvae from south to north, known also from glass eels, which makes evaluation of length increase from west to east even more difficult. A higher age of glass eels in the north than in the south is therefore likely.
\end{abstract}

\section{INTRODUCTION}

The larvae of Anguilla anguilla take part in probably the longest migration of its genus (4000 to $6000 \mathrm{~km}$ ), before arriving at the coasts of the continents of Europe and Africa at the glass-eel stage. Calculating their age is an important step towards understanding the life cycle and population dynamics of the juvenile $A$. anguilla. One method of obtaining age and growth data is to examine length frequency distributions over a certain period and over the whole geographic range of the population. A survey which comprises all larvae lengths during a certain seasonal period requires an enormous effort; surveys on eel larvae, therefore, are very rare (Tesch, 1982; Kracht, 1982; Tesch \& Wegner, 1990; Boëtius \& Harding, 1985b).

The conclusion of Schmidt (1922) from his own material that the larvae take $2 \frac{1}{2}$ to 3 years to reach the European continental waters was criticized by Boëtius \& Harding (1985a), on reexamination of Schmidt's material, as being probably too long although indirect evidence also favoured a three-year migration (Harden Johns, 1968).

These contradictory discussions led Lecomte Finiger (1994) to study the daily rings of the otoliths of the eel larvae applying methods described in Japanese examinations 
and assisted by the fact that daily rings can develop on leptocephalus otoliths. She obtained an average count of about 200 rings in glass eel otoliths and came to the conclusion that, including the time of metamorphosis, the European glass eels are less than one year old. For several reasons this short larval life span seems to be unrealistic: (1) Deposition rate of the rings has never been validated directly. (2) Calculated hatching dates are incompatible with times of spawning estimated from temporal distribution of small leptocephali. (3) Ages of leptocephali calculated from putative daily rings would require unrealistically high speeds of transport or swimming to Europe (McCleave 1996; Tesch 1983, page 90). (4) A study on the microstructure of not only glass eels but also of eel leptocephali before metamorphosis showed that age determination of glass eel otoliths was impossible because of an uncountable area of the otolith before metamorphosis (Antunes \& Tesch, 1997). For age determination, one therefore has to return to the mentioned length frequency distribution of eel larvae caught in different seasons and areas of the North Atlantic.

\section{MATERIAL AND METHODS}

Length frequency data of eel larvae (Anguilla spp.) caught in different geographical locations in the North Atlantic, as listed in different publications, were used for the identification of possible different age groups (Fig. 1). In addition to the method of Bhattacharya (1964) used by Kracht (1982), the method of MacDonald \& Pitcher (1979) was applied.

Growth during the first year of life was estimated by Boëtius \& Harding (1985a) and by Kleckner \& McCleave (1985) on the basis of all available length data pooled for several years, whereby geographical area and migratory progress were not considered. I preferred to differentiate between years, cruises and those stations which provided more than 20 specimens, or in special cases more than 10 individuals. For instance, I used the series of stations from one cruise in a restricted area from May 1st to 28th, and calculated the mean length of the larvae at each geographical station. The different mean lengths at the stations for that 28-day period were then used in a linear regression of length against time (Fig. 2). In order to obtain an average length increase for the spring-summer period the minimum and maximum lengths of all regression lines are combined by a single regression line (Fig. 3)

\section{RESULTS}

\section{Year classes present in the North Atlantic}

The only material which could show the length frequency distribution during one complete season and over the whole distance from the spawning area to the European coast is that of the German two-ship cruise of 1979. Figure 1a shows the length frequency distribution from the spring of 1979 by combining the material from two publications, one dealing with the small (0-group) larvae (Schoth \& Tesch, 1982) and the other with the larger larvae (Kracht, 1982). Two distinct and clearly separate peaks are visible, demonstrating that, in the spring, at least two year classes are present in the North Atlantic. The first peak, around $12 \mathrm{~mm}$, belongs to the new year-class hatched in March-April 1979, age group 0 (AG 0 ). The second peak at $47 \mathrm{~mm}$ can only be attributed to the larvae which hatched in the previous spring, indicating the AG I. As well as these two distinct groups, 

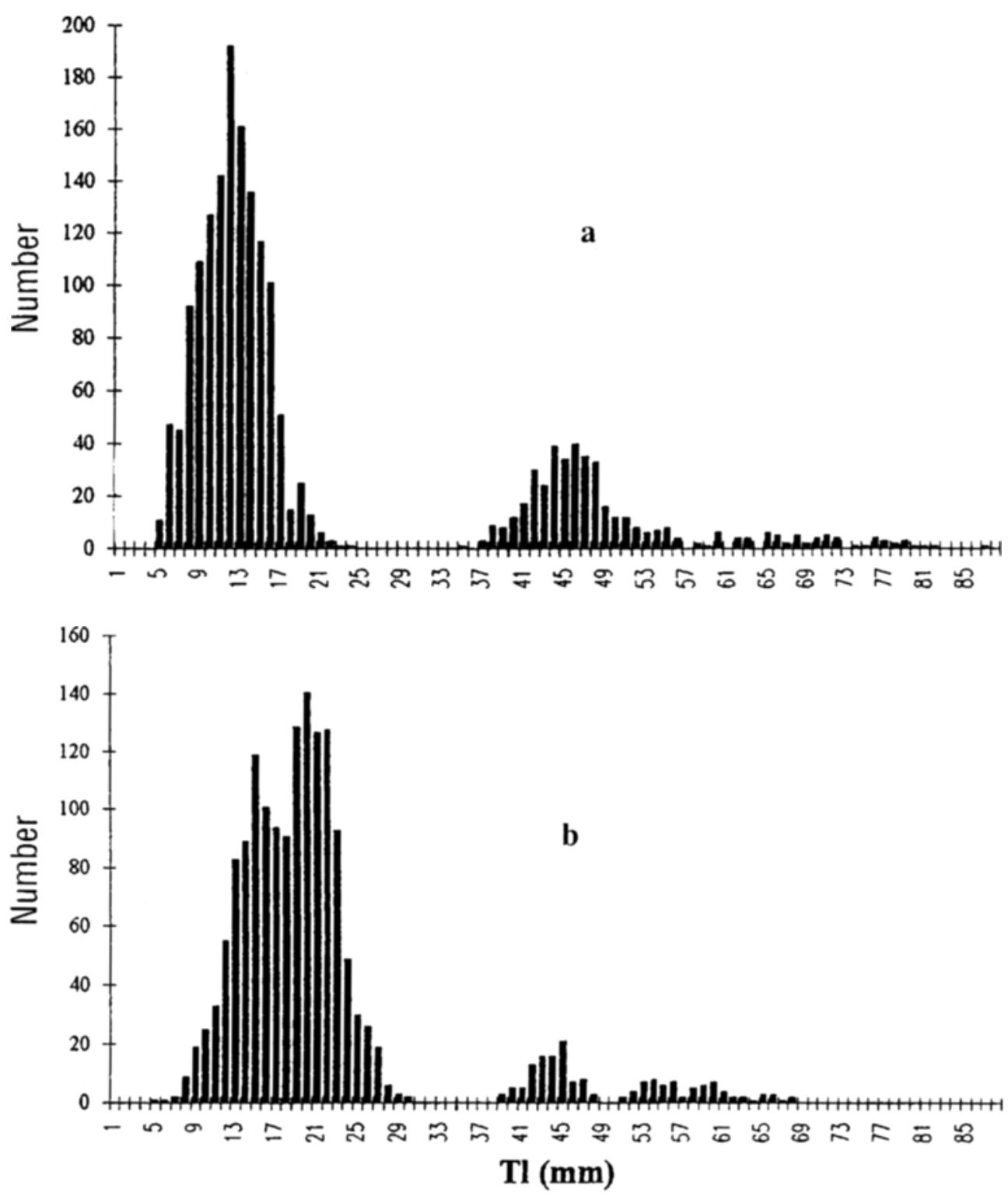

Fig. 1. Length frequency distribution of eel larvae (Anguilla anguilla) in the North Atlantic: investigated in (a) 1979, based on the combined samples of Schoth \& Tesch (1982) and Kracht (1982), and collected from 22nd March to 6th May between the central spawning area and $35^{\circ}$ to $48^{\circ} \mathrm{N} 07^{\circ} \mathrm{W}$ (Tesch, 1982); (b) 1922, based on Schmidt's collections of "Dana II" from 29th April to 14th June between the central spawning area and $37^{\circ} 40^{\prime} \mathrm{N} 26^{\circ} 00^{\prime} \mathrm{W}$ (revised data, published by Boëtius \& Harding, 1985b). $\mathrm{Tl}=$ Total length 


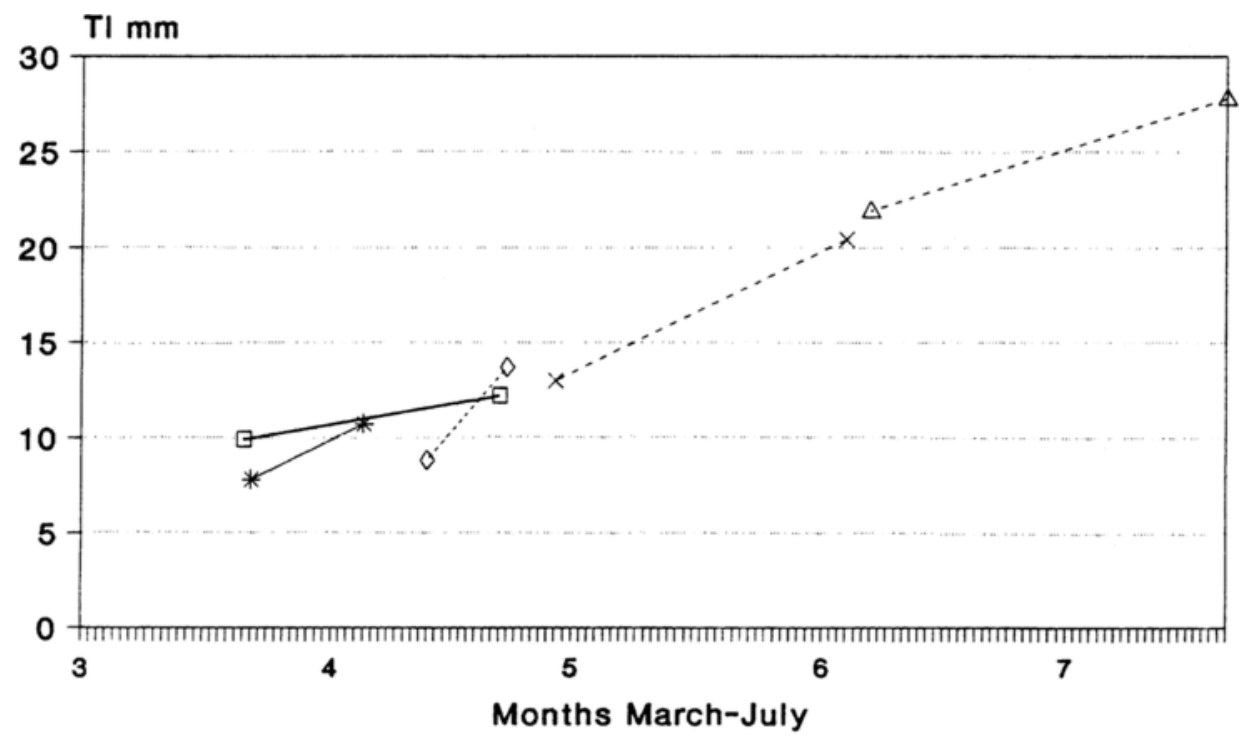

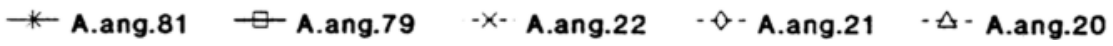

Fig. 2. Different periods of growth for the first year larval life of $A$. anguilla obtained by length measurements of larvae sampled during more or less long periods of sampling in 1920,1921, 1922, 1979, 1981 (for Lit. cit. see legend to Fig. 1). The increase in length during each period is described by the linear regression line $(r=0.55 ; 0.50 ; 0.83 ; 0.41 ; 0.55$, respectively) of the different mean lengths of samples from the respective periods

there are still larger larvae present. Kracht (1982), using the method of Bhattacharya (1964), considered those larger larvae to be a further age group and suggested they were AG II, which is similar to Schmidt's (1922) conclusion. Whatever age group they may belong to, either to fast growers of AG I or to a normally growing older age group, they are, less numerous than AG 0 and AG I. The AG I was exclusively captured between the centre of the spawning area $\left(60^{\circ} \mathrm{W}\right)$ and $40^{\circ} \mathrm{W}$, an area from where, starting in the month of April, they could never reach the European continent during the same spring.

With the possible exception of the "Dana II" cruise in spring and early summer 1922, none of the Dana cruises provided length frequency distributions from the spawning ground to the European continental shelf. This "Dana II" cruise carried out a survey from the spawning area (about $65^{\circ}$ ) to as far east as $40^{\circ} \mathrm{W}$ only. The length frequency distribution of the larvae is presented in Figure $1 \mathrm{~b}$. The first peak $(18 \mathrm{~mm})$ is for larvae from the spawning area near $60^{\circ} \mathrm{W}$, captured from May to early June, the second peak (44 mm) is for larvae captured from the beginning of June between $40^{\circ}$ and $45^{\circ} \mathrm{W}$. There is also a peak at a length of $58 \mathrm{~mm}$ which is clearer than in the corresponding 1979 data (Fig 1a) and should not be interpreted as AG I. The length frequency peaks of the possibly three age groups in 1922 and 1979 could therefore be interpreted as follows:

late spring 1922: 18-44-(58) $\mathrm{mm}$

spring 1979: 12-47-(68) $\mathrm{mm}$ 
The relationship of standard deviation and standard errors (sigma/SE) of the three age groups in 1979 show strong positive differences $(3.25 / 0.063 ; 3.99 / 0.175 ; 7.30 / 0.918)$ which is in accordance with the existence of separate age groups. This is also true for AG I and AG II in 1922 (2.1/0.187; 0/0.578). AG 01922 is separated into two groups. It is not likely that they present different age groups because the sampling took place over a much longer period than in 1979 which could produce different peaks. This is discussed in more detail below. For the years 1983 (April) and 1984 (March), McCleave (1996) presented slightly smaller length frequency distributions of the AG 0 (around 10 and $9 \mathrm{~mm}$ resp.) which accord to the earlier time of the year.

\section{Growth during the first year}

Length increase during the first year of larval life (AG 0) of Anguilla anguilla has been estimated by Boëtius \& Harding (1985a) at $0.177 \mathrm{~mm}$ per day and for A. rostrata at 0.187 per day. Kleckner \& McCleave (1985) calculated a faster daily growth rate of $0.24 \mathrm{~mm}$ per day for A. rostrata. The discrepancy between the Danish and the North American calculations is not surprising and is caused perhaps by the different and sparse material and, perhaps, by the calculation with pooled material.

In the present calculations all regressions were positive which reflects length increases, but shows also varying rates of growth between periods (Fig. 2) which is probably the consequence of local and annual variations as well as of, in some cases, the rather small sample size.

The average length increase for almost the whole summer period calculated on the basis of all these single regression lines is shown by the regression line in Figure 3 . A similar calculation is included for A. rostrata. From the regression line for European eel larvae, a growth of $0.15 \mathrm{~mm}$ per day can be calculated for the periad between March 20 th and July 21st. Extrapolation to the beginning of winter, the 1st of November, results in a length of $41.2 \mathrm{~mm}$. To see whether this is realistic or not, data from comparatively large samples of one of the rare cruises in autumn earlier this century (1913) are used ("Margarethe" data from Boëtius \& Harding, 1985b). A linear regression of the lengths (8 samples; $n=432 ; r=0.39$ ) from September 26 th to November 24 th (area: $28^{\circ}$ to $39^{\circ} \mathrm{N}, 48^{\circ}$ to $60^{\circ} \mathrm{W}$ ) provided estimated lengths of $38.1 \mathrm{~mm}$ for the beginning and $40.9 \mathrm{~mm}$ for the end of this period which is more in accordance with the first year growth of this study. It corresponds to a daily growth of $0.05 \mathrm{~mm}$, a third of that of the summer.

By extrapolation to a hatching length of $4 \mathrm{~mm}$, the time of hatching is found to be February 21 st. Both the estimated length in autumn and spawning time are not far from expected values, especially when the length of AG I in spring is considered (Fig.1:44-47 $\mathrm{mm}$ ). This corresponds to a length increase in the winter months of about $5 \mathrm{~mm}$ and a daily length increase of not more than a fifth of that of the first summer. Similarly, $A$. rostrata is calculated to have a growth of $0.22 \mathrm{~mm}$ per day and is extrapolated to have a length of $61.0 \mathrm{~mm}$ on the $1 \mathrm{st}$ of November which is also close to the length of metamorphosis after the generally accepted one summer growing period. Peak hatching is calculated to occur on February 13th. These are also "reasonable" values and confirm the faster growth of the American eel originally suggested by Schmidt (1922) and confirmed since by other observations (Kleckner \& McCleave, 1985).

From the above data on length frequencies and from the calculation of growth in the 


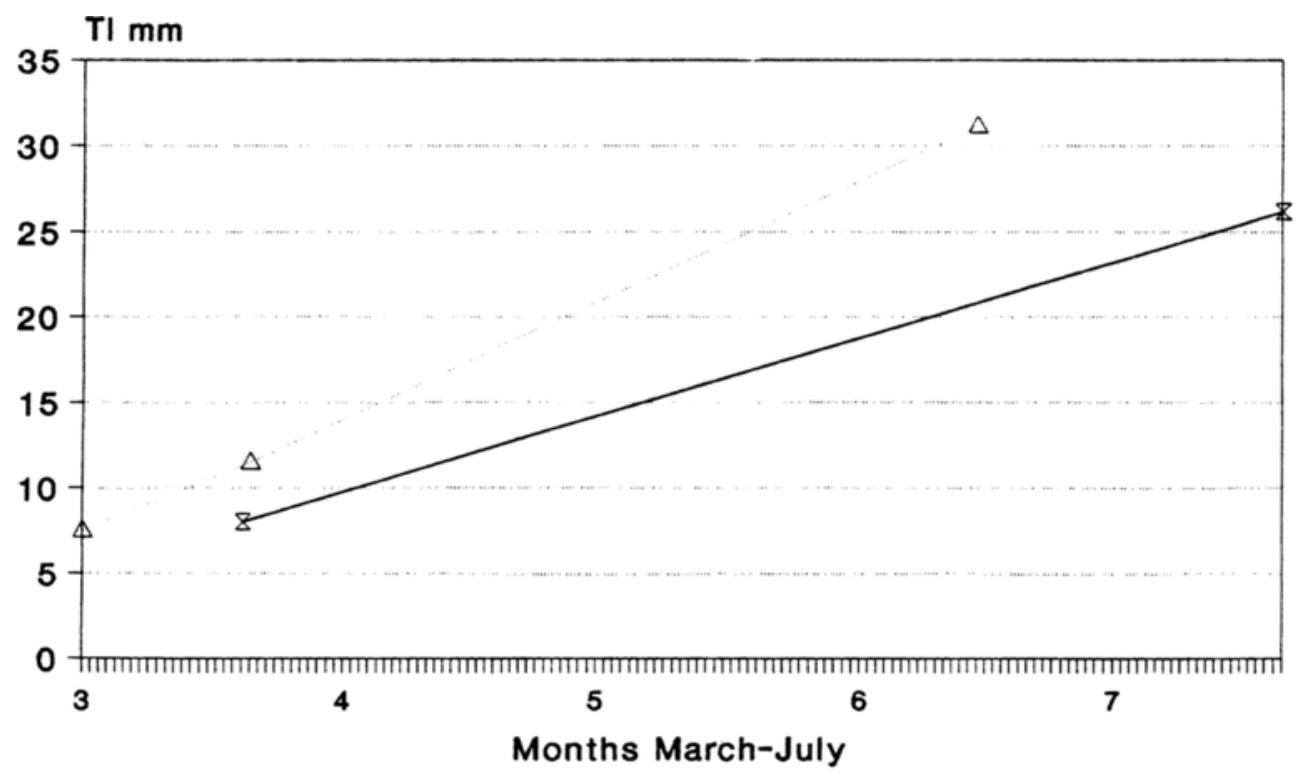

\section{$\triangle$ A.rost.1920-81 $\varangle$ A.ang.1920-81}

Fig. 3. First year growth of $A$. anguilla (below) calculated by linear regression $(r=0.97)$ using the length at the beginning and at the end of each of the regressions in Fig. 2. For comparison, the growth of $A$. rostrata, calculated in the same way $(r=0.95)$, is included (above), using in addition the smallest and earliest larvae (Febr. 26th to March 3rd, 1981) of Kleckner et al. (1985)

first year of life of the European eel, lengths in the early to late autumn are estimated at about $40 \mathrm{~mm}$. Until the following spring, length increase therefore is small because the length frequencies for spring 1922/79 (Fig. 1) show a total length of about $45 \mathrm{~mm}$ only. Low temperature and short day length in winter, which are reasons for low production, are probably reasons for the slow growth rate of only $0.05 \mathrm{~mm}$ during the 6 winter months, or probably even less $(0.03 \mathrm{~mm}$ per day).

Decreasing growth in autumn should also have its effect on the formation of daily rings on the otoliths. After formation of about 200 rings, no further daily rings are produced and, instead of that, a mainly diffuse area is visible (Antunes, 1994; Antunes \& Tesch, 1997).

\section{Age and growth after the first year}

From the statistical evaluation of Schmidt's (1922) and our own larval material, it seems uncertain whether the eel larvae become glass eels after the first year or after further years. A step forward towards solving this problem may be the consideration of the growth after the first year. Using the lengths at age I and at the suggested age II (see above; Fig. 1), approximate annual growth rates may be calculated:

$$
\begin{aligned}
& 192257 \mathrm{~mm}-43 \mathrm{~mm}=14 \mathrm{~mm} \text { in } 12 \text { months or } 0.04 \mathrm{~mm} \mathrm{day}^{-1} \\
& 197968 \mathrm{~mm}-45 \mathrm{~mm}=23 \mathrm{~mm} \text { in } 12 \text { months or } 0.06 \mathrm{~mm} \mathrm{day}^{-1}
\end{aligned}
$$


Growth during the second year may be faster if six winter months of comparatively slow growth are excluded from the calculation. It may be 0.06 (1922) to 0.09 (1979) day ${ }^{-1}$. Summer growth in the second year therefore would decrease to less than half of that of the first year. It is therefore reasonable that, after the much reduced growth of the first winter, visible daily rings on the otoliths are not formed during the comparatively slow growth in the suggested following second summer.

Given the suggested lengths of "AG II" of 57 or $68 \mathrm{~mm}$, the final length of eel larvae as known from the northern areas is not attained. In the Bay of Biscay, a length of about

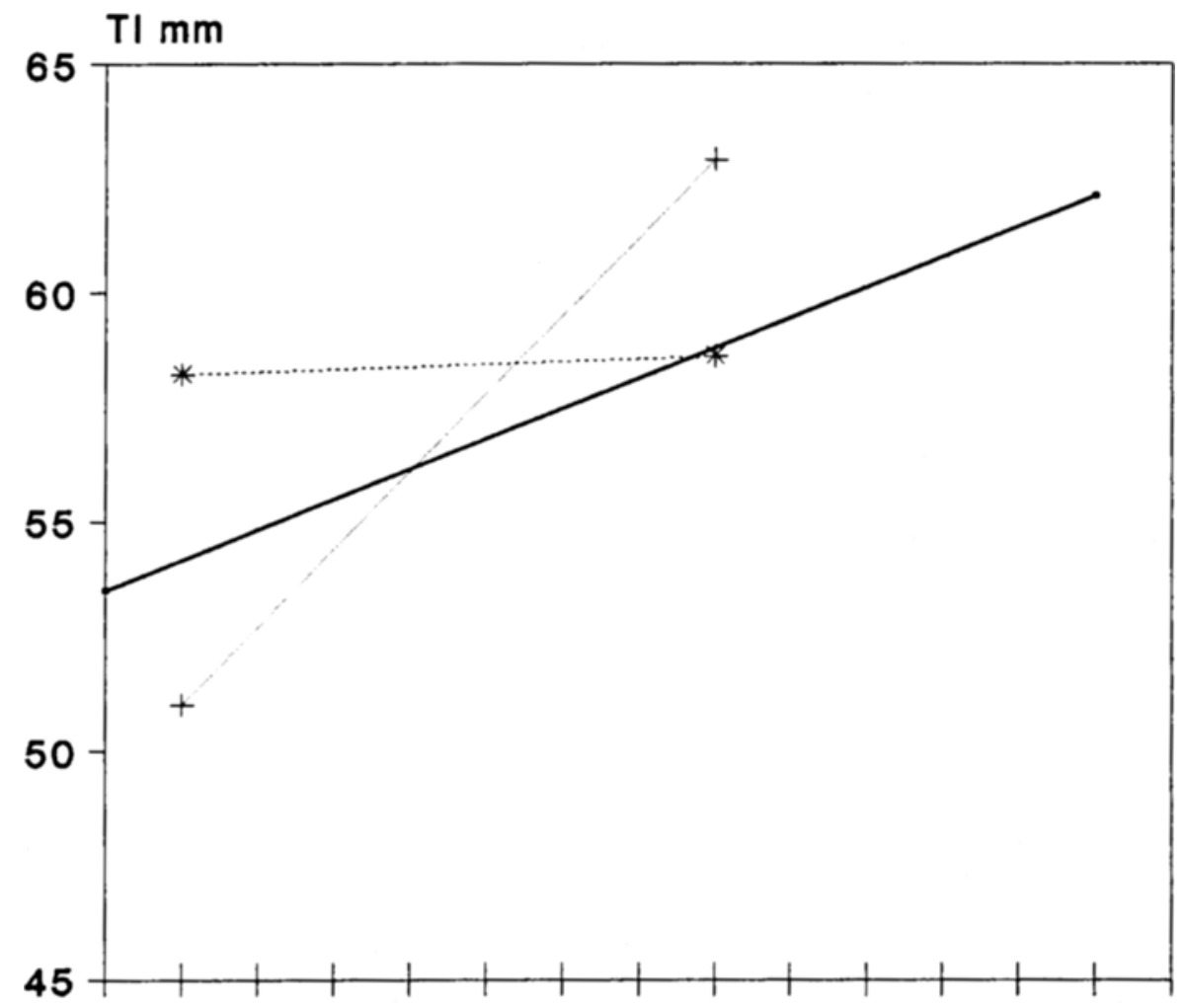

\section{Days or degrees}

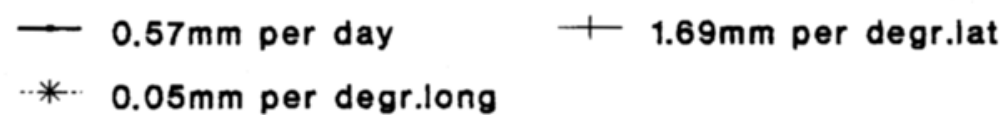

Fig. 4. Increase of length over time $(r=0.76)$ of $A$. anguilla, by latitude from south to north $(r=0.85)$ and by longitude from west to east from June 11 th to 25 th, 1931 (Coeff. cor. 0.04), calculated on the basis of the linear regression of ten "Dana II" samples taken by J. Schmidt (Boëtius \& Harding, $1985 \mathrm{~b}, \mathrm{pp} .222-224$ ) in the area from $31^{\circ}$ to $44^{\circ} \mathrm{N}$ and $24^{\circ}$ to $32^{\circ} \mathrm{W}$, including two samples of $\mathrm{n}<20$ 
$75 \mathrm{~mm}$ would require a length increase of a further $7 \mathrm{~mm}$. Growth in the assumed "third year" therefore is still far less than in the "second year". This may be attributed to the summer months up to September and the metamorphosis when the first glass eels arrive in the Bay of Biscay. If this assumption is correct it is not at all surprising that daily growth rings on the otolith are not formed or cannot be distinguished.

Age and annual length increase have also to be appraised in the light of the length increase from south to north (Kracht, 1982), which, in glass eels, from Gibraltar to the Bay of Biscay, is about $10 \mathrm{~mm}$ (Tesch et al., 1986; see also Boëtius \& Harding, 1985b: pp. 210-211, Dana II, Stat. 2998 and 9515). For the larvae along the continental slope, Kracht (1982) found a difference of $6 \mathrm{~mm}$ from south to north and, as far west as the AG I area in the North Atlantic a $7 \mathrm{~mm}$ difference. Length increases in time, longitude and latitude based on data of J. Schmidt, obtained by "Dana II" in June 1931 as far west as $26^{\circ}$ to $32^{\circ} \mathrm{W}$ (Boëtius \& Harding, 1985a) are shown in Figure 4. Although there are strong increases related to time $(r=0.76)$ and from south to north $(r=0.85)$ no increase from west to east is obvious ( $r=0.04)$. Similarly, Kracht (1982) calculated nearly double the growth increase from south to north $\left(0.7 \mathrm{~mm} \cdot\right.$ degree latitude $\left.\mathrm{e}^{-1}\right)$ compared to that from west to east. The difficulty of differentiating between an age group length increase and an increase from south to north is therefore considerable. For this reason, it is likely that larvae near Gibraltar are not the same age as those in the Bay of Biscay or areas farther north; they could perhaps be up to one year younger.

A discussion on the existence of older larvae than AG I based on present larvae material is not conclusive. However, considering both the length frequency distributions of the Eastern North Atlantic eel larvae presently available, and the unidentifiable large diffuse zone on the otoliths of larvae and glass eels (Antunes \& Tesch, 1995), a possible existence of two- to three-year old glass eels on the North-East Atlantic shelf areas is likely.

Acknowledgements. I wish to thank Volker Siegel for his help in analysing length frequency distributions by the "MacDonald/Pitcher" method, also Don Jellyman and Carol Berger for their assistance in improving the English text.

\section{LITERATURE CITED}

Antunes, C., 1994. Estudo da migraçao e metamorfose de Anguilla anguilla L. por análise dos incrimentos dos sagittae, em leptocéfalos e enguias de vidro. Diss. Ciéncias Biomédicas, Univ. Porto, Portugal, $294 \mathrm{pp}$.

Antunes, C. \& Tesch, F.-W., 1997. A critical consideration of the metamorphosis zone when identifying daily rings in otoliths of European eel, Anguilla anguilla L. - Ecol. Freshwat. Fish, 6 , 102-107.

Bhattacharya, C. G., 1964. A simple method of resolution of distribution into Gaussian components. - Biometrics 23, 115-135.

Boëtius, J. \& Harding, E. F., 1985a. A re-examination of Johannes Schmidt's Atlantic eel investigations. - Dana 4, 129-162.

Boëtius, J. \& Harding, E. F., 1985b. List of Atlantic and Mediterranean Anguilla leptocephali: Danish material up to 1966. - Dana 4, 163-194.

Harden Jones, F. R., 1968. Fish migration. Arnold, London, 825pp.

Kleckner, R. C. \& McCleave, J. D., 1985. Spatial and temporal distribution of American eel larvae in relation to North Atlantic Ocean current systems. - Dana 4, 67-92.

Kleckner, R. C., Wippelhauser, G. S. \& McCleave, J. D., 1985. List of Atlantic Anguilla leptocephali: American material. - Dana 4, 99-128. 
Kracht, R., 1982. On the geographic distribution and migration of I- and II-group eel larvae as studied during the 1979 Sargasso Sea expedition. - Helgoländer Meeresunters. 35, 321-327.

Lecomte-Finiger, R., 1994. The early life history of the European eel. - Nature, Lond. $370,424$.

MacDonald, P. D. M. \& Pitcher, T. J., 1979. Age groups from size frequency data: a versatile and efficient method of analysing distribution mixtures. - J. Fish. Res. Bd Can. 36, 987-1001.

McCleave J. D., 1996. Do leptocephali of the European eel swim to reach continental waters? Conflicting results from biology and oceanography. - EIFAC/ICES Working Group on eel in IJmuiden, The Netherlands, $18 \mathrm{pp}$. (unpubl.)

Schmidt, J., 1922. The breeding places of the eel. - Phil. Trans. R. Soc. (B). 211, 178-208.

Schoth, M. \& Tesch, F.-W., 1982. Spatial distribution of 0-group eel larvae (Anguilla sp.) in the Sargasso Sea. - Helgoländer Meeresunters. 35, 309-320.

Tesch, F.-W. 1982. The Sargasso Sea eel expedition 1979. - Helgoländer Meeresunters. 35, $263-277$.

Tesch, F.-W., 1983. Der Aal. 2. Aufl., Parey, Hamburg, 340 pp.

Tesch, F.-W. \& Wegner, G., 1990. The distribution of small larvae of Anguilla sp., related to hydrographic conditions 1981 between Bermuda and Puerto Rico. - Int. Revue ges. Hydrobiol. 75, 845-858.

Tesch, F.-W., Niermann, U. \& Plaga, A., 1986. Differences in development stage and stock density of the larval Anguilla anguilla off the west coast of Europe. - Vie Milieu 36, 255-260. 